\title{
Access to Information in the Age of Trump
}

\section{Nicole Schoenberger}

Word Count (excluding references): 5207

\begin{abstract}
As a primary supplier of information and research of importance and value to the public, the government's activity in doing so must be subject to scrutiny. This paper examines access to information under the government's control within the context of the current United States presidential administration. After providing an overview of access to information, the paper moves to a discussion of current issues, highlighted by actions taken by the Trump administration. Of particular interest are the removal of information from government websites and gag orders or other restrictions imposed on government agencies. These have led to a lack of transparency as well as concerns regarding the authority and reliability of government data. In these ways, the Trump administration has limited and significantly harmed access to information. The paper also makes connections to larger information policy concerns, ending with a discussion of ways to promote access to government information.
\end{abstract}

Keywords: Donald Trump; access to information; government information

Schoenberger, N. (2018). Access to information in the age of Trump. Emerging Library \& Information Perspectives, 1, 6-33. https://doi.org.10.5206/elip.v1i1.360 


\section{Access to Information}

Access to information directly impacts individuals' ability to use information. Yet, while 'access to information' may seem straightforward, it is in fact composed of several underlying aspects: physical, intellectual, and social access. Physical access refers to a person's capacity to access the information, whether a physical or virtual document, and intellectual access relates to whether information presented in a document can be understood (Burnett, Jaeger, \& Thompson, 2008, pp. 57-58). Finally, social access concerns normative influences as to how information is viewed and accessed (Burnett et al., 2008, p. 58). Before any of these forms of access can be considered, however, information must first be made available.

Shepherd (2015) has characterized the right to access information as an essential element of citizens' rights, as well as being integral to 'trust in public discourse and transparent, accountable and open government" (p. 715). Trust in the government is not only an important consequence of providing access to information, but also part of a larger picture that includes consideration of what type of information is being made available. This paper demonstrates how actions taken by the Trump administration limit and significantly harm access to information. By examining access to information as a concept and focusing on how it is affected by government policies and actions, we gain an understanding of how restricting access to information threatens the integrity of information that is available. Limiting access to information also undermines the basis of democratic societies.

Citizens must have access to information to be adequately informed about issues that may impact them. As Mark Fenster (2017) has argued, "Advocates must persuade 
legislators, administrators, and the public why information disclosure should be a top administrative priority" (p. 174). Unfortunately, reviewing recent presidential approaches to brokering access to information reveals an uneven commitment to this cause. The George W. Bush administration, for example, removed information from government websites, ignored FOIA requests, and outsourced management of the latter to third party private contractors with minimal public accountability (Jaeger, 2007, p. 846). On the other hand, Barack Obama's administration valued transparency and increased access to government information. Once in office, Obama used executive orders to require government agencies to "err on the side of openness" when dealing with FOIA requests for government records (Jaeger \& Bertot, 2010, p. 372). These differing perspectives indicate that presidential views towards access to information have enormous potential to affect what information will and will not be available.

Some of the Trump administration's moves to curtail access to information have echoed those of the Bush administration. As Jaeger (2007) has stated, one of Bush's first acts once in office was to "eviscerate" many federal government websites, removing information without archiving it (p. 846). This signalled the beginning of a continuing trend towards restricting and controlling what information is made available

to the public. Through actions such as removing government information from websites and issuing gag orders to government agencies, the Trump administration has decreased transparency and jeopardized the reliability of government information.

\section{Democracy}

Access to information is closely tied to democracy, particularly in conjunction with the concept of the public sphere. As theorized by Jürgen Habermas (1974), the public 
sphere is a realm in which public opinion is formed with guaranteed access for all citizens (p. 49). It is built on the democratic demand for public access to information, acting as a mediator between the state and society (Habermas, 1974). Democracy requires access to meaningful information, both of a social and a political nature (Jaeger \& Bertot, 2010). The public sphere offers a space within society, independent of the government, for the free flow of information and discussion of civic concerns necessary for democracy (Buschman, 2005). Access to information fosters the democratic process, and democratic countries tend to be more transparent and typically make more information available than authoritarian governments (Jaeger \& Bertot, 2010). Without adequate access to government information, the public sphere is restricted and full participation in democracy becomes impossible.

The right of access to information has been indicated in key documents, such as the 1948 United Nations Universal Declaration of Human Rights, which includes the right to "seek, receive and impart information" (Shepherd, 2015, p. 715). In the United States, access to information has been inextricably linked to individuals' right to seek out the information that public authorities, such as the government, hold. This ideal was expressed by Thomas Jefferson, who said that "the people must have 'full information"' because "the basis of our governments [is] the opinion of the people" (as cited in Schwarz, 2013, p. 649). Given that the government is such a major source of information, it is very concerning when an administration seeks to restrict access to government information. This is especially true in a country as influential as the United States, which collects a vast amount of information of international significance. 


\section{Legislation \& Case Law}

Access to government information is not without legal precedent. Goals of transparency and openness were formalized in the 1967 Freedom of Information Act (FOIA), making the United States the first country to guarantee a legal right to request government information (Jaeger \& Bertot, 2010; Shepherd, 2015). The FOIA affords individuals the right to request access to federal agency records, except for those that could compromise national security, personal privacy, or law enforcement if released (FOIA.gov, n.d.). While the FOIA has been amended several times, one of the most notable instances is the Electronic Freedom of Information Act Amendments, which requires agencies to make information available electronically. Other amendments have enabled the expanded release of national security information (Department of Justice, 1996; United States v. Weatherhead, 1999). The FOIA establishes the foundation for access to information issues that will be examined in the latter part of this paper.

Beyond the FOIA, several court cases have dealt with the subject of access to information. A key case concerning the right to access government records is that of Houchins v. KQED, Inc., (1978), which arose from a television station being denied entry to a county jail following an inmate's suicide (Adams, 2013). The court ruled that the press' right to access penal facilities is not greater than that of the general public, and that the right to access government information or information under the government's control is not mandated by either the first or fourteenth amendments (Adams, 2013; Houchins v. KQED, Inc., 1978). Several years earlier, judges in United States v. Nixon (1974) unanimously found that there is no "absolute, unqualified, presidential privilege to withhold information." In Richmond Newspapers, Inc. v. Virginia 
(1980), the court upheld an appeal to a judge's decision to close a trial to the media and public, stating that the First Amendment extended to the right to attend trials as well as the "freedom to listen and to receive information and ideas." These cases, among others, indicate that access to information is a complicated topic, and the question of how much should be accessible is a multi-faceted one.

\section{International Connections}

Based on recent political developments, several significant politicians appear to hold views similar to those espoused by Trump administration. Fenster (2017) points to Nigel Farage, Marine Le Pen, Vladimir Putin, and Silvio Berlusconi as representing "a countermovement away from democratic institutions" (p. 173). Having such individuals in positions where they have the power to shape information policy and restrict what information is available is troubling. Such perspectives are not universal, however. More than 100 countries have enacted freedom of information legislation, demonstrating the global importance of this area of law. In addition to the United States, other countries with such legislation include South Africa, Japan, Fiji, India, Sweden, the Netherlands, Trinidad and Tobago, Canada, and Australia (Mendel, 1999; Shepherd, 2015).

With the aim of improving accountability and transparency, the United Kingdom passed the Freedom of Information Act in 2000, which provides a comprehensive overview of the rights of citizens and authorities concerning access to information (Shepherd, 2015). While the act exempts Security and Intelligence Services as well as the Royal family, the UK Parliament is subject to it (Shepherd, 2015). Returning to North America, Canada also has legislation protecting access to information, with the Access to Information Act being the most prominent example. Enacted in 1983, it accords 
everyone in Canada the right to access records over which the government has control (Access to Information Act, 1985; Government of Canada, 2015). Furthermore, the act takes precedence over any disclosure prohibitions with "quasi-constitutional" status and applies unless otherwise stated in the act (Government of Canada, 2015). Despite the legislation, access to government information in Canada is not without problems. In her most recent annual report (2016-2017), Information Commissioner Suzanne Legault points to several points where the act falls short (Office of the Information Commissioner of Canada, 2017). While the act requires the government to respond to requests for information within 30 days, the system often fails to meet this timeline, and it contains loopholes that allow agencies to withhold information. These issues are compounded by a lack of funding for transparency measures in the most recent federal budget (Bronskill, 2017).

Legault's report also assigns government agencies grades for 2015-2016, which are calculated by dividing the number of information requests completed past the statutory deadline by the number completed before the deadline (Office of the Information Commissioner of Canada, 2017). Canada Revenue Agency, the RCMP, and Global Affairs all received grades of $F$, meaning that more than $20 \%$ of their information requests were completed after the deadline (Office of the Information Commissioner of Canada, 2017). Both Health Canada and the Department of National Defence received the more serious red alert status, which indicates that extremely high percentages of requests $-41 \%$ and $42 \%$, respectively - were closed after the 30 day deadline (Bronskill, 2017; Office of the Information Commissioner of Canada, 2017). Given the value of the information held by these agencies, delayed access or outright 
rejections of requests is worrying. The Office of the Information Commissioner has also been investigating the censoring of scientists by the Harper government. Though the investigation was launched in 2013 and was intended to be finished prior to the publication of the 2016-2017 annual report, the findings have not yet been released (Duck, 2017).

Advances in the legal realm have been mixed as well. In 2010, Ontario (Public Safety and Security) v. Criminal Lawyers' Association found that freedom of expression includes the right to request access to government documents, especially when their suppression would impede essential discussion of matter relating to public interest. However, the case also determined that privileged information can continue to be withheld (Makin, 2012). As the above overview of current access to information legislation in Canada and the United Kingdom illustrates, it is not just the United States that continues to reassess the balance between access and government regulation. However, the degree to which the Trump administration is undermining access to information is without parallel among today's other major democracies.

\section{Disappearance of Government Data}

While the advent of digital information has facilitated easier access and many have come to expect government information to be readily available, it is also easier to restrict access to digital content (Jaeger \& Bertot, 2010). Indeed, immediately following Trump's inauguration, his administration deliberately removed information from the Whitehouse.gov website. Although some changes are expected as part of administrative changeover, such as transferring access to the official @POTUS Twitter account, the noteworthy point here is that information was removed. Among other 
changes, all detailed information about climate change was taken down, with the exception of Trump's promise to roll back the environmental policies from Obama's administration (Davenport, 2017).

At the 100-day point, this information remained missing and without replacement, other than an "America First Energy Plan," stating that the United States has been held back by "burdensome regulations" (Lakely, 2018). President Trump has emphasized his commitment to eliminating what he terms "harmful and unnecessary policies" like the Climate Action Plan (Peacock, 2017). Even one year into the Trump's presidency, a search for "climate change" in the "Energy \& Environment" section of the whitehouse.gov site yielded just two news clips, an executive order on Energy Independence and Economic Growth, and a fact sheet outlining Trump's actions in regard to environmental issues. The fact sheet highlighted clearing regulations on energy production, removing "job-killing restrictions" on oil, shale, and natural gas energy, and preventing harm to the coal industry (Whitehouse.gov, 2017). Climate change was only mentioned in passing in an Executive Order rescinding "Executive and Agency actions centered on the previous administration's climate change agenda that have acted as a road block to energy independence" (Whitehouse.gov, 2017).

In addition to public expectations for access to material, the United States' international influence and the authoritativeness of their climate change data means that the removal, or attempted suppression, of this information could have far reaching consequences (Davenport, 2017). Unsurprisingly then, concerns about the disappearance of climate change data have sparked widespread initiatives to preserve information at risk of being deleted. 314 Action, a non-profit group, gathers scientists at 
universities around the country to conserve vital climate data on greenhouse gas emission rates, sea level measurements, and atmospheric temperature trends from NASA, the Environmental Protection Agency, the National Oceanic and Atmospheric Administration, and the U.S. Geological Survey websites (Davenport, 2017). Other projects include the Internet Archive's "End of Term 2016" DataRefuge project, the Environmental Data and Governance Initiative, and a "guerrilla archiving" event in December 2016 at the University of Toronto. These initiatives have all sought to ensure continued access to information at risk of being suppressed by the Trump administration (Calma, 2017; Dennis, 2016; Milman \& Morris, 2017; Peacock, 2017).

These attempts speak to the importance of climate change data as well as access to information more generally. As noted above, the recent access to information changes under the Trump administration echo those of another Republican president: George W. Bush. In that administration there was also significant mismanagement of environmental data, including altering Environmental Protection Agency (EPA) reports on climate change and global warming. This had marked a stark departure from the general trend of presidents using policy to promote access to information (Jaeger, 2007). While such policies dictate what information the public can access, they also have wider effects on society and its collective consciousness. Historically, government policies limiting the public's access to information have had negative impacts, ranging from "inflaming mid-twentieth century paranoia about Communist infiltration of the U.S. government to protecting the Iran-Contra affair" (Jaeger, 2007, p. 845).

In a contemporary context, restrictions on access to information regarding climate change could limit the public's understanding of, or belief in, climate change and 
its adverse effects. This, in turn, could minimize resistance to domestic projects such as the North Dakota Access Pipeline. Because the United States also plays a key economic and political role in global policy discussions (Aldy, 2017, p. 380; Etty et al., 2017, p. 2), the Trump administration's actions could also have a lasting impact internationally. For example, withdrawing from the Paris Agreement may pave the way for other countries to back away from similar policies.

\section{Gag Orders}

The Trump administration has also issued gag orders to government agencies, and this action presents another threat to the public's ability to access timely government information. Specifically, the Environmental Protection Agency, the United States Department of Agriculture, the Department of the Interior, Department of Health and Human Services, and the Department of Transportation have all been directed to restrict the amount of public content they publish (Lartey, 2017). Although there is not a consensus on the level of the restrictions-whether they constituted an order or a recommendation - the larger cause for concern lies in the type of information subject to suppression. In an article for The Guardian, Jamiles Lartey noted that the agencies targeted by gag orders all publish data relating to climate change (2017). Furthering this connection, more details about the nature of the restrictions came forward when the Badlands National Park (under the Department of the Interior) defied the order earlier this year, tweeting about the amount of atmospheric carbon dioxide. These tweets were later deleted and said to have been posted by former employees without authorized access (Volcovici \& Huffstutter, 2017). 
Such gag orders and removal of tweets may have an impact on the public's belief that the information received from government agencies is both accurate and complete. While a lack of access to information is problematic, a less obvious issue arises if the public believes they have full access, when in reality information may be only partially available or restricted altogether. Beyond eroded trust and the potential for inaccurate information, selective publication creates a false sense of consensus or confidence (Crabtree \& Davenport, 2017; Nature Cell Biology, 2017). As a result, the impact of restricted information access extends beyond what the public can and cannot access, ultimately shaping narratives. Attempts to limit access must also be scrutinized insofar as they negatively affect democratic institutions by limiting the public's understanding of current issues (Crabtree \& Davenport, 2017). The public's false sense of being informed may then erode the possibility for a genuinely democratic process. Using presidential authority to control what governmental agencies can publish, particularly in terms of information that would serve the public interest, is troubling, and one should consider what motivated these gag orders.

Volcovici and Huffstutter (2017) ponder the possibility of actions such as gag orders being used to discourage dissenting views. In this case, Trump, who they refer to as a "climate change doubter," is attempting to curtail research that implicates carbon dioxide emissions from fossil fuels as a contributor to global warming (Volcovici and Huffstutter, 2017). Expecting individuals in political office, even presidents, to refrain from holding personal opinions is unreasonable, but using their position to restrict access to information to further a personal agenda is unacceptable. Through reflecting on Bush's actions, Jaeger's (2007) discussion of attempts to control scientific research 
by blocking publication, consolidating application peer reviews, and promoting selfcensorship may easily be applied to Trump's current attempts to control climate change information through gag orders. Curated public knowledge is also a consequence of previously available information being removed, in addition to the danger of undue influence over scientific inquiry and dissemination.

When evaluating access to information, the Trump administration's actions not only restrict available data and public access, but also limit the depth and breadth of scientific inquiry. Indeed, the administration has not limited its directives on language restrictions to research areas related to climate change. On December 15, 2017, the Washington Post published a list of seven terms that the Centers for Disease Control and Prevention (CDC) has been prohibited from using in its official documents, particularly those sent to CDC partners and Congress (Golden, 2017; Sun \& Eilperin, 2017). These terms are: entitlements, vulnerable, diversity, transgender, fetus, evidence-based, and science-based. Replacements for most of these terms were not included, but it was advised that in place of the last two terms the CDC should state that it "bases its recommendations on science in consideration with community standards and wishes" (Sun \& Eilperin, 2017). This "ban" does not apply to every single document the CDC produces, as it is primarily intended for budgetary documents and funding applications. A CDC official characterized these prohibited terms as a budget strategy rather than an attempt to censor research (Golden, 2017).

Asking researchers to explain their work in terms reflecting the current administration's ideological priorities shifts their focus away from furthering potentially lifesaving research and towards a new kind of political correctness. Absent from the 
prohibited term list are suggestions for researchers working on areas such as prenatal development or AIDS in the transgender population. While replacing prohibited terms with blank spaces may follow the directive, this would not be helpful from a research standpoint. Restricting the environment in which research can occur, as well as potentially reduced funding for such research at the CDC or the National Institutes of Health, would stifle research, with far reaching consequences (Golden, 2017; Nature Cell Biology, 2017; Sun \& Eilperin, 2017). Laboratories and research institutes may be limited in what research they can undertake, resulting in less information overall. Such a dearth in research output could also translate to fewer medical or environmental advances, which would affect not only the United States, but the global community.

\section{Authority \& Reliability of Government Information}

When the credibility of what the government says and the information it releases is compromised, it becomes difficult to determine the accuracy of information. Information of value may be disregarded because of the difficulty in assessing its accuracy, while false information may be accepted without question. In addition to the lack of confidence that unverified government information inspires, weakened reliability results in an increased vulnerability to disasters or attacks, as information and statements coming from the government sources will be subject to suspicion (Sunlight Foundation, 2017). When information output is taken seriously, public perception of threats is shaped by what the government focuses on and how it frames information. The capacity for government information to shape public opinion can be gleaned from the American public's perception of a high threat of terrorism, especially when compared to other countries such as Canada (Jaeger, 2007, p. 852). Though subject to a number of tragic 
terror related events, the amount of attention paid to this threat in the United States by politicians and the media has resulted in an inflated sense of risk.

In a broader context, the information made public and prioritized by the government directs public focus, ultimately shaping discourse within the public sphere to match an administration's priorities. The degree to which this politicizes access to information cannot be discounted. Without transparency, changes to government websites endanger public access to information. Jaeger (2007) has written of the impact of restrictions introduced under the Bush administration, which resulted in researchers being reluctant to undertake research in certain areas to avoid government interference with the research results. If the Trump administration is restricting information in a similar fashion, one can imagine that suppressing information about climate change might have a comparable result. This threat of self-censorship is also present in the prohibition of certain terminology in CDC funding documents. If specific terms are discouraged, so too will medical research focused on these topics.

Also concerning is the Trump administration's appointment of individuals to government agencies despite clear conflicts in terms of their priorities. For instance, Scott Pruitt has been a "leading advocate" against environmental protections and even sued the EPA, but he was appointed head of the agency (Mooney, Dennis, \& Mufson, 2016). More recently, there has been conflict over Trump's naming of Mick Mulvaney as the acting head of the United States Consumer Financial Protection Bureau. Mulvaney previously worked to eliminate the bureau, describing it as a "sad, sick joke" (Rucker \& Mason, 2017). Such appointments undermine agencies' authority, in addition to compromising the credibility and reliability of their subsequent actions and information 
output. Under these appointments, certain information may be withheld from the public, and future information accessible to the public may be unreliable and less plentiful. The efforts of citizens and watchdog groups to preserve data are encouraging; however, as a lawyer for the Center for Biological Diversity has pointed out, "Scrubbing information about climate change will not make it any less dangerous" (Milman \& Morris, 2017). Placing skeptics in leadership positions gives them the power to redirect or weaken scientific inquiry, regulations, and measures to protect society.

\section{Transparency}

Discussions of the Trump administration and the transparency, or lack thereof, of its actions often focus on the absence of information to support policy decisions. This extends beyond limiting available climate change data and muzzling agencies. Ultimately, the administration is using the lack of transparency to hide not only the end product (e.g., environmental information), but more critically the process, inhibiting public understanding of how policy decisions are made by only making their outcomes visible. According to the Sunlight Foundation's (2017) review of government transparency, the Trump administration has had a chilling effect on "communication, collaboration, and proactive disclosure" of the government's actions. Specific incidents include the lack of on-camera press briefings since the end of June 2017, secret White House visitor logs, missing policy documents, and a deregulatory agenda run by secret

teams. These examples, while not comprehensive, illustrate restricted access to information, not only when contained in documents, but also regarding governmental functions and processes. 
A "technocratic" understanding of transparency focuses on information that must be disclosed, and it is enforceable through laws and regulations (Fenster, 2017). Compliance with technocratic transparency occurs when information is made available to the public and can be accessed with relative speed and ease. Alongside this is "moralistic" transparency, which is premised on the notion that "the state must refrain from hiding itself and the truth from the public" (Fenster, 2017, p. 173). More difficult to concretely quantify than its technocratic counterpart, moralistic transparency is gauged by perceptions of honesty and authenticity. While Trump's frequent use of Twitter and his often outrageous rhetoric may indicate some level of authenticity, the legitimacy of these communication modes is debatable based on both meanings of transparency. The technocratic meaning is at odds with policies like the Trump administration's decision to ignore senators' information requests unless issued by committee chairs, which limits Democrats' ability to gain information without the support of a Republican chairman (Bresnahan, 2017). As governmental agencies are required to comply with FOIA requests, such attempts to hide information indicates a clear violation of technocratic transparency.

Returning to the previous focus on climate change information, even cases of withholding or removing information that is not required to be made publicly available contravene the spirit of the transparency requirements. Because federal government transparency and the accountability that comes with it is paramount, systematically and blatantly hiding information is highly troubling. Even with the FOIA as an advocacy model, the United States "might be departing from the long arc of transparency's ascent under a Trump administration" (Fenster, 2017, p. 173). Now more than ever there is a 
need for access to information and transparency. Still, as Dennett (2017) has cautioned, rather than expecting utter and unreserved transparency, the public must know "enough to make informed choices, the very foundation of democracy" (p.47). Transparency is also a crucial element of building and maintaining trust between the government and the public. Without public trust in the government and the information it makes available, there is a serious risk of political disengagement (Jaeger \& Bertot, 2010, p. 371).

\section{Looking Forward}

Having provided an overview of current threats to access to government information in the United States, this section shifts to a discussion of policies that could help to minimize the negative impacts on society. Crucially, freedom to information "establishes a statutory right to access information" (Shephard, 2015, p. 717). Given the relationship between access to government information and democracy, access to information cannot and should not be diminished. Any restrictions to information access limit the extent to which citizens can participate in government and assert their rights. This is coupled with the dangers of incomplete or inaccurate information, particularly in terms of its tendency to impede citizens' ability to make informed decisions (Crabtree \& Davenport, 2017). Fortunately, the threat of government information disappearing under Trump has increased awareness of the importance of access to information and encouraged measures intended to protect information. The so-called "Beetlejuice provision," which requires agencies to make any information requested three separate times publicly available online, has been used by groups to gain access to previously removed data and even prevent information from being lost forever (Milman \& Morris, 
2017; Sullivan, 2017). While the cause of these efforts is regrettable, there have been some positive outcomes.

Democratic participation in the public sphere is facilitated by access to "substantive" information about citizens' rights as well as political and social issues and government activity (Jaeger, 2007). Even the United Nations has acknowledged the importance of access to information, proclaiming freedom of information a fundamental human right, such that access to information is required for a "democratic way of life" (Mendel, 1999). The United Nations does not dictate the extent of access to information in any country, but its stance does illustrate the importance of this matter. Despite the vital nature of access to information, it is important to remember that a right to access information does not, in itself, guarantee unlimited access to information. Access to information must also be valued throughout society. Indeed, it is not only the public that should be aware of and willing to fight for access, but also organizations, including courts, governments, and institutions.

The physical, intellectual, and social aspects of information access addressed in the background section provide a framework to craft an information access policy. While these may not be the first considerations when evaluating access to government information, without them in place, achieving full access is impossible. Physical access requires information infrastructure with access points so that the public knows what information exists as well as where and how to access it (Burnett et al., 2008). Maintaining intellectual access calls for organizing and displaying information in a way that is understandable. In other words, intellectual access encompasses how information is categorized, organized, displayed, and represented (Burnett et al., 2008). 
Finally, the social aspect involves the value of information as determined by social groups' norms (Burnett et al., 2008). Given the challenges outlined in this paper, a good starting point would be to foster an internal culture supportive of information access. Anyone charged with managing information should strive to increase access to information, rather than promoting their own political values and dismissing information with which they do not agree.

By analyzing the Trump administration's removal of information from government websites and use of gag orders, this paper has demonstrated contemporary threats to access to information. While the paper highlighted the Trump administration's treatment of climate change information, it also argued that this is indicative of a broader attempt to curtail access and shape public discourse. This has resulted in a lack of transparency that calls into question the authority and reliability of government information, while also preventing the public from fully participating in a democratic society. Though not referring specifically to Trump's administration, Jaeger (2007) provides an excellent summary of the issues at stake:

In facilitating or limiting the ability of individuals, social groups, and government organizations to access information, policy can ensure access or prevent access, making some information off limits and protecting the right to access other information $[\ldots]$ further, information access is of utmost importance in democratic societies; without sufficient access to information, political discourse and democratic dialogue are hampered (p. 841).

The Trump administration's actions that have been the focus of this paper reflect the concerns in Jaeger's overview. The present political climate in the United States 
encapsulates why it is necessary to continue fighting for unhindered access to information. For a democratic society, or at least one in which the public can have faith in the information they receive from the government, access to information is paramount. Only when information is made publicly accessible can its integrity be maintained. This, in turn, can help foster the continuation of scientific research and a vibrant public sphere. 


\section{References}

Access to Information Act, R.S.C. c. A-1 (1985). Retrieved from: http://lawslois.justice.gc.ca/eng/acts/A-1/page-1.html

Adams, T. (2013, November 26). Freedom of information laws and the First Amendment. OLR Research Project. Retrieved from https://www.cga.ct.gov/2013/rpt/2013-R-0439.htm

Aldy, J. E. (2017). Real world headwinds for Trump climate change policy. Bulletin of the Atomic Scientists, 73(6), 376-381. doi:10.1080/00963402.2017.1388673

Bresnahan, J. (2017, June 02). Democrats outraged by Trump ban on info requests. Politico. Retrieved from http://www.politico.com/story/2017/06/02/democratstrump-ban-oversight-requests-239087

Brief Amici Curiae of The Reporters Committee for Freedom of the Press and the Society of Professional Journalists in support of Respondent, United States. V. Weatherhead, 528 U.S. 1042 (1999) (no. 98-1904). Retrieved from https://www.rcfp.org/news/documents/weatherhead.html\#III

Bronskill, J. (2017, June 18). Information watchdog says government using access law as "shield" against openness. $C B C$. Retrieved from http://www.cbc.ca/news/politics/ access-to-information-act-report-1.4151446

Burnett, G., Jaeger, P. T., \& Thompson, K. M. (2008). Normative behavior and information: The social aspects of information access. Library and Information Science Research, 30(1), 56-66. doi:10.1016/j.lisr.2007.07.003

Buschman, J. (2006). Libraries and the decline of public purposes. Public Library Quarterly, 24(1), 1-12. https://doi.org/10.1300/J118v24n01_01 
Calma, J. (2017, December 27). Vive la résistance: 10 ways people stood up for the planet in 2017. Grist. Retrieved from http://grist.org/article/vive-la-resistance-10ways-people-stood-up-for-the-planet-in-2017/

Crabtree, C., \& Davenport, C. (2018). Contentious politics in the trump era. PS: Political Science \& Politics, 51(1), 17. doi:10.1017/S104909651700141X

Davenport, C. (2017, January 20). With Trump in charge, climate change references purged from website. The New York Times. Retrieved from https://www.nytimes.com/2017/01/20/us/politics/trump-white-house-website.html

Dennett, D. (2017, March 31). Fake News Isn't The Greatest Threat To Democracy. Total Transparency Is. Retrieved from https://www.huffingtonpost.com/entry/fakenews-transparency-trump_us_58dd8a54e4b0e6ac7093b460

Dennis, B. (2016, December 13). Scientists are frantically copying U.S. climate data, fearing it might vanish under Trump. The Washington Post. Retrieved from https://www.washingtonpost.com/news/energyenvironment/wp/2016/12/13/scientists-are-frantically-copying-u-s-climate-datafearing-it-might-vanish-under-trump/

Department of Justice. (1996, January 01). FOIA Update: The Freedom of Information Act, 5 U.S.C. sect. 552, As Amended By Public Law No. 104-231, 110 Stat. 3048. Retrieved from https://www.justice.gov/oip/blog/foia-update-freedominformation-act-5-usc-sect-552-amended-public-law-no-104-231-110-stat

Duck, T. (2017, June 16). Information commissioner strangely silent on muzzled scientists. National Observer. Retrieved from 
http://www.nationalobserver.com/2017/06/16/opinion/information-commissioner$\underline{\text { strangely-silent-muzzled-scientists }}$

Etty, T., Heyvaert, V., Carlarne, C., Farber, D., Huber, B., \& Lin, J. (2017). Transnational environmental law on the threshold of the trump era. Transnational Environmental Law, 6(1), 1-10. doi:10.1017/S2047102517000012

Fenster, M. (2017). Transparency in Trump's America. Governance, 30(2), 173-175. doi:10.1111/gove.12272

FOIA.gov. (n.d.). Freedom of Information Act: Frequently asked questions. Retrieved from https://www.foia.gov/faq.html\#thefoia

Golden, H. (2017, December 22). Did Trump ban words at the CDC? The full story is less simple. Elite Daily. Retrieved from https://www.elitedaily.com/p/did-trumpban-words-at-the-cdc-the-full-story-is-less-simple-7635956

Government of Canada. (2015, April 10). Treasury Board Manual: Access to Information. Retrieved from https://www.canada.ca/en/treasury-boardsecretariat/services/access-information-privacy/access-information/accessinformation-manual.htm|\#cha1 1

Habermas, J. (1974). The public sphere: An encyclopedia article. (S. Lennox \& F. Lennox, Trans.). New German Critique, 3, 49-55.

Houchins v. KQED, Inc., 438 U.S. 1 (1978). Retrieved from https://supreme.justia.com/cases/federal/us/438/1/case.html Jaeger, P. T., \& Bertot, J. C. (2010). Transparency and technological change: Ensuring equal and sustained public access to government information. Government Information Quarterly, 27(4), 371-376. doi:10.1016/j.giq.2010.05.003 
Jaeger, P. T. (2007). Information policy, information access, and democratic participation: The national and international implications of the Bush administration's information politics. Government Information Quarterly, 24(4), 840-59. doi:10.1016/j.giq.2007.01.004

Lakely, J. (2018, January 11). An America First Energy Plan. Retrieved from https://www.heartland.org/publications-resources/publications/an-america-firstenergy-plan

Lartey, J. (2017, January 26). US federal communications crackdown: What we know and what we don't. The Guardian. Retrieved from https://www.theguardian.com/us-news/2017/jan/26/us-federal-agencycrackdown-epa-sean-spicer

Makin, K. (2012, August 23). Supreme Court establishes constitutional right to information - within limits. The Globe and Mail. Retrieved from https://www.theglobeandmail.com /news/national/supreme-court-establishesconstitutional-right-to-information-within-limits/article1608321/

Mendel, T. (1999). Freedom of information as an internationally protected human right. Retrieved from https://www.article19.org/data/files/pdfs/publications/foi-as-aninternational-right.pdf

Milman, O., \& Morris, S. (2017, May 14). Trump is deleting climate change, one site at a time. The Guardian. Retrieved from https://www.theguardian.com/usnews/2017/may/14/donald-trump-climate-change-mentions-government-websites Mooney, C., Dennis, B., \& Mufson, S. (2016, December 08). Trump names Scott Pruitt, 
Oklahoma attorney general suing EPA on climate change, to head the EPA. The Washington Post. Retrieved from https://www.washingtonpost.com/news/energyenvironment/wp/2016/ 12/07/trump-names-scott-pruitt-oklahoma-attorneygeneral-suing-epa-on-climate-change-to-head-the$\underline{\text { epa/?utm term }=. \text { b25300fe10ca }}$

Nature Cell Biology. (2017). Science in the age of Trump. Nature Cell Biology, 19(409). doi:10.1038/ncb3526

Office of the Information Commissioner of Canada. (2017). Annual Report 2016-2017. Retrieved from http://www.oic-ci.gc.ca/eng/rapport-annuel-annual-report 20162017.aspx

Ontario (Public Safety and Security) v. Criminal Lawyers' Association, 2010 SCC 23 (2010). Retrieved from https://scc-csc.lexum.com/scccsc/scc-csc/en/item/7864/index.do

Peacock, T. (2017, April 28). 100 days of Trump: Where are key WhiteHouse.Gov pages? Peacock Panache. Retrieved from http://www.peacockpanache.com/2017/04/100-days-trump-whitehouse-gov-30936.html

Richmond Newspapers, Inc. v. Virginia, 448 U.S. 555 (1980). Retrieved from https://supreme.justia.com/cases/federal/us/448/555/case.html

Rucker, P., \& Mason, J. (2017, November 27). U.S. consumer watchdog agency official sues to block Trump's pick. Reuters. Retrieved from https://www.reuters.com/article/us-usa-trump-cfpb/u-s-consumer-watchdogagency-official-sues-to-block-trumps-pick-idUSKBN1DQ0NX 
Schwarz, F. A. (2013). Access to government information is a foundation of American democracy - but the courts don't get it. Oklahoma Law Review, 65(4), 645-664. Retrieved from https://heinonline.org/HOL/P?h=hein.journals/oklrv65\&i=691

Shepherd, E. (2015). Freedom of information, right to access information, open data: Who is at the table? The Round Table: The Commonwealth Journal of International Affairs, 104(6), 715-726. doi:10.1080/00358533.2015.1112101

Sullivan, C. C. (2017, March 28). Could FOIA's 'beetlejuice' provision save public access to gov't data?. Retrieved from http://blogs.findlaw.com/technologist/ 2017/03/could-foias-beetlejuice-provision-save-public-access-to-govt-data.html

Sun, L. H., \& Eilperin, J. (2017, December 15). CDC gets list of forbidden words: Fetus, transgender, diversity. The Washington Post. Retrieved from https://www.washingtonpost.com/national/ health-science/cdc-gets-list-offorbidden-words-fetus-transgender-diversity/ 2017/12/15/f503837a-e1cf-11e7$\underline{89 e 8-e d e c 16379010 \text { story.html?utm term }=.096 f a 91 \text { aa4ee }}$

Sunlight Foundation. (2017, July 20). On Trump, transparency and democracy. Sunlight Foundation. Retrieved from https://sunlightfoundation.com/2017/07/20/trumpadministration-open-government-record/

United States v. Nixon, 418 U.S. 683 (1974). Retrieved from https://supreme.justia.com/cases/federal/us/418/683/case.html

Volcovici, V., \& Huffstutter, P. J. (2017, January 24). Trump administration seeks to muzzle U.S. agency employees. Reuters. Retrieved from http://www.reuters.com/ article/us-usa-trump-epa-idUSKBN15822X 
Whitehouse.gov. (2017, March 28). President Trump's Energy Independence Policy. Retrieved from https://www.whitehouse.gov/briefings-statements/presidenttrumps-energy-independence-policy/ 